doi: $10.15407 /$ ukrbotj73.02.178

\author{
D.V. LEONTYEV \\ Kharkiv State Zooveterinary Academy \\ 1, Akademichna Str., Kharkiv, 62134, Ukraine \\ protista@mail.ru
}

\title{
THE EVOLUTION OF SPOROPHORE IN RETICULARIACEAE (MYXOMYCETES)
}

Leontyev D.V. The evolution of sporophore in Reticulariaceae (Myxomycetes). Ukr. Bot. J., 2016, 73(2): 178 -184.

Kharkiv State Zooveterinary Academy

1, Akademichna Str., Kharkiv, 62134, Ukraine

protista@mail.ru

\begin{abstract}
Recent molecular studies have clarified the phylogenetic relations within the family Reticulariaceae (Myxomycetes, Myxogastrea), allowing to reconstruct the ways of the morphological evolution within the family. We conclude, that the general tendency of the sporophore evolution in Reticulariaceae was the transformation of the stalked forms to the sessile ones, followed by the development of the metameric sporophores, called pseudoaethalia and aethalia, from the separate sporocarps. The common ancestor of the family was similar to Alwisia lloydiae having stalked sporocarps and tubular capillitium. At least four evolutionary lineages originated form this ancestor: 1) Alwisia $\rightarrow$ Tubifera, 2) Alwisia $\rightarrow$ Rigidotubula (and probably Siphoptychium), 3) Alwisia $\rightarrow$ (Lycogala) $\rightarrow$ Thecotubifera, 4) Alwisia $\rightarrow$ Lycogala $\rightarrow$ Reticularia. In each of these branches, the processes like a loss of stalks, transition from spherical to elongated sporothecae, transformation of solitary sporocarps to grouped ones, a loss of capillitium and formation of pseudocapillitium, have occurred independently. Therefore, the type of the fruiting body, and presence of capillitium or pseudocapillitium, cannot be considered as sufficient criteria for separating myxomycete genera.
\end{abstract}

Key words: $18 \mathrm{~S}$ rDNA, aethalium, capillitium, convergence, paralellism, phylogeny, pseudoaethalium, pseudocapillititum, spore ornamentation, sporocarp, sporotheca.

Myxogastrea, or Myxomycetes, are the group of ameboid eukaryotes, able to produce macroscopic fruiting bodies of complicate structure. Within the group, five orders and about twelve families are traditionally recognized, among which the family Reticulariaceae is characterized by the absence of true capillitium and pseudoaethaliate or aethaliate structure of the fruiting bodies (NannengaBremekamp, 1991; Neubert et al., 1993; Lado, Pando, 1997; Ing, 1999; Poulain et al., 2011).

The traditional understanding of the taxonomical structure and discriminative features of Reticulariaceae was reconsidered in our recent study, based on the 18S rDNA phylogeny (Leontyev et al., 2014a; 2014b; 2015). The family, with a few exceptions, appeared to be a monophyletic taxon, subdivided to at least six clusters, which corresponds to the genera Alwisia Berk. \& Broome, Lycogala Adans., Reticularia Bull., Tubifera G.F. Gmel., Rigidotubula ad int. and Thecotubifera ad int., among which Alwisia was reerected (Leontyev et al., 2014a; 2014b), and two last names are to be published as new to science. One more genus, the recently re-erected Siphoptychium Rostaf., was united with Reticulariaceae based on morphological data (Leontyev, 2015).

The genera Reticularia and Tubifera, species Alwisia bombarda Berk. \& Broome, Lycogala (C) D.V. LEONTYEV, 2016 epidendrum (L.) Fr., Tubifera ferruginosa (Batsch) J.F. Gmel., and T. dictyoderma Nann.-Bremek. \& Loer. in their traditional understanding appeared to be polyphyletic. A revision of these taxa, based on morphological and molecular data, allowed to describe 9 new species: Alwisia lloydiae Leontyev, S.L. Stephenson et Schnittler, A. morula G. Moreno, Leontyev, D.W. Mitch., S.L. Stephenson, C. Rojas \& Schnittler, A. repens Leontyev, Schnittler, G. Moreno, S.L. Stephenson, D.W. Mitchell \& C. Rojas, Tubifera applanata Leontyev \& Fefelov, T. corymbosa Leontyev, Schnittler, S.L. Stephenson \& L.M. Walker, T. dudkae (Leontyev \& G. Moreno) Leontyev, Moreno \& Schnittler, T. magna Leontyev, Schnittler, S.L. Stephenson \& T. Kryvomaz, T. montana Leontyev, Schnittler \& S.L. Stephenson, T. pseudomicrosperma Leontyev, Schnittler \& S.L. Stephenson, and two subspecies: T. ferruginosa subsp. ferruginosa Leontyev, Schnittler \& S.L. Stephenson and T. ferruginosa subsp. acutissima Leontyev, Schnittler \& S.L. Stephenson (Leontyev et al., 2014a; 2014b; 2015). Two more species (Rigidotubula reticulata ad int., $R$. violacea ad int.) and one new combination (Thecotubifera dictyoderma ad int., comb. nov. pro Tubifera dictyoderma Nann.Bremek. \& Loer.) are prepared for the publication.

The species of Reticularia which have warty spores with olive, golden-yellow or brown pigmentation 
Fig. 1. Phylogeny of the Reticulariaceae based on 18S rDNA5'-domain sequences. The tree was constructed by Bayesian Inference. ML bootstrap replicates above 50 and Bayesian posterior probabilities above 0.5 are shown for each branch. A hyphen indicates a conflicting topology. The scale bar indicates the fraction of substitutions per site. Asterisk: the genotype displayed by the type specimen of the respective taxon.

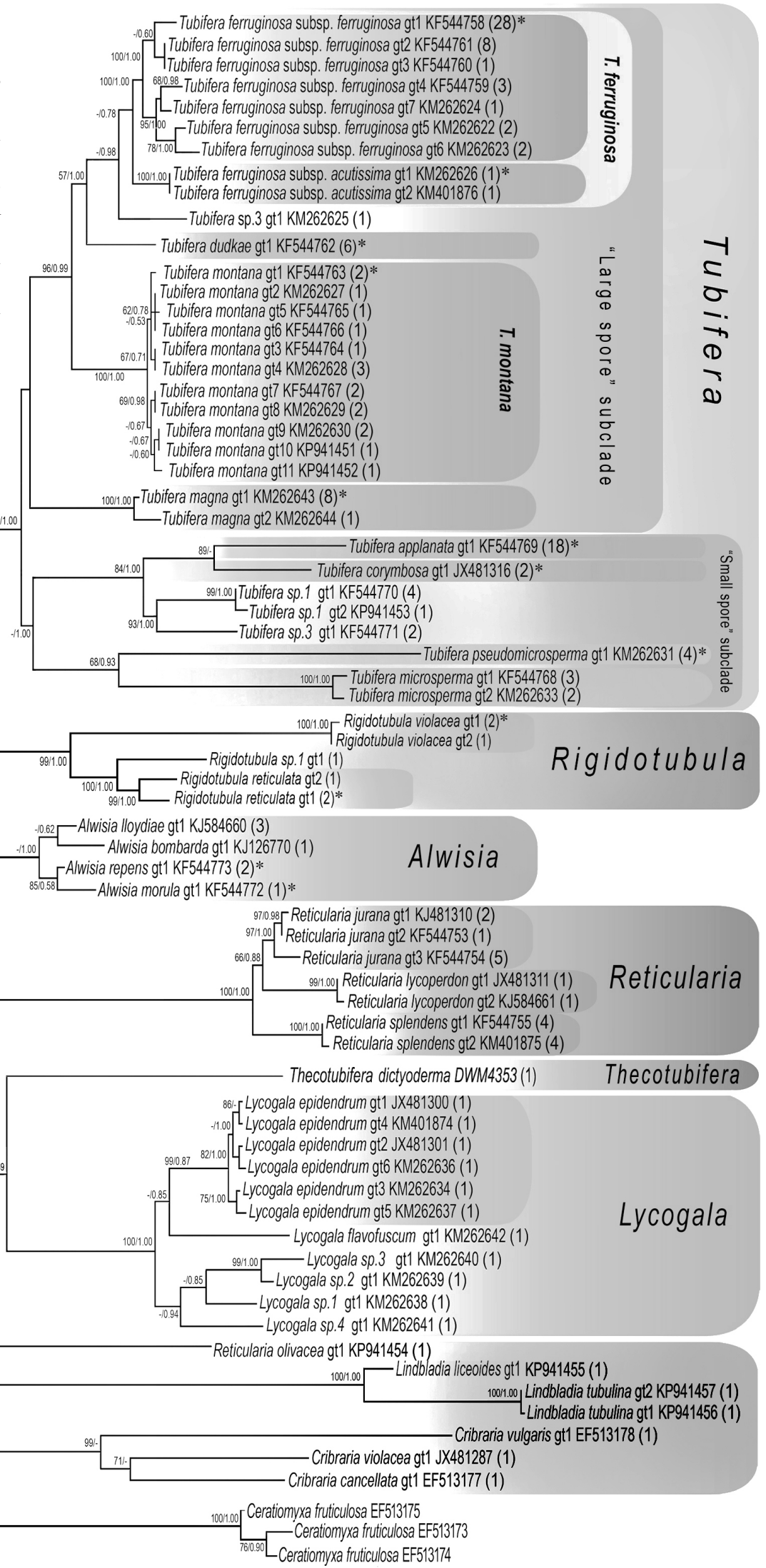




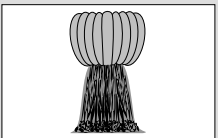

Tubifera microsperma, T. pseudomicrosperma

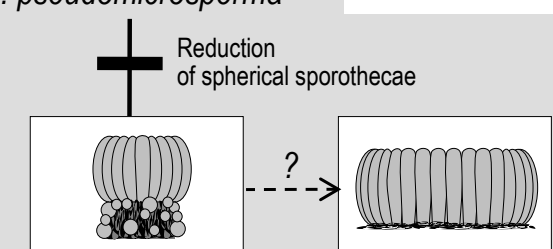

Tubifera dimorphotheca Tubifera applanata

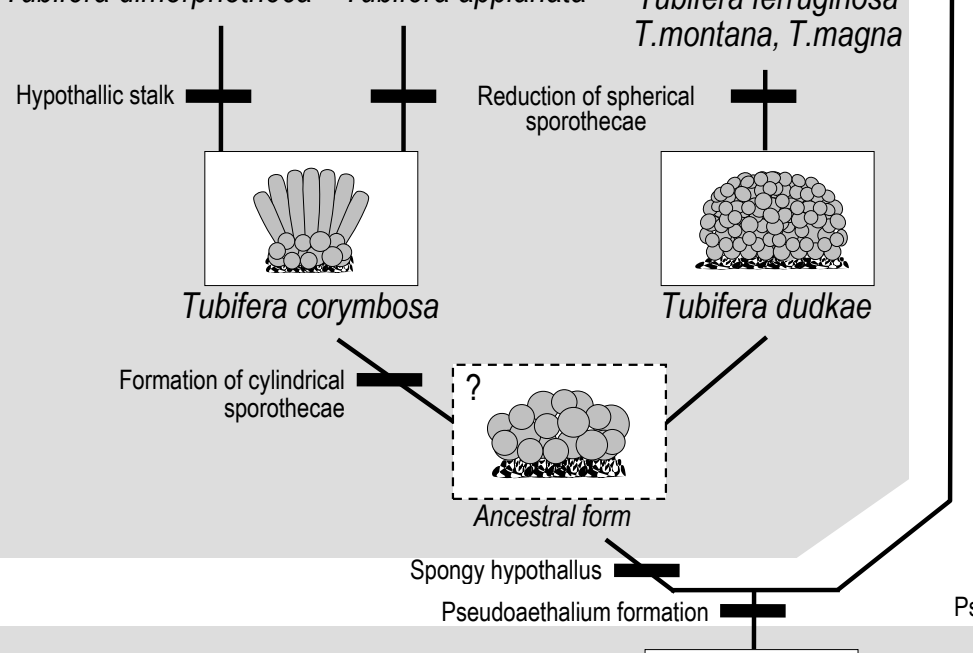

\section{Alwisia}

Siphoptychium?
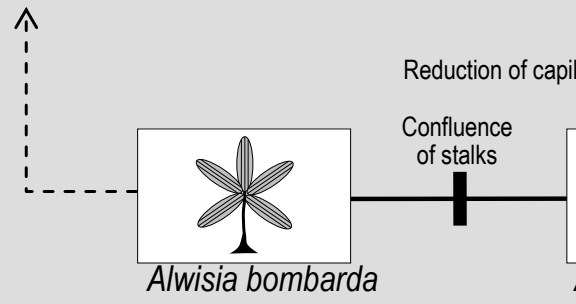

Formation of columella

Cartilaginous peridium

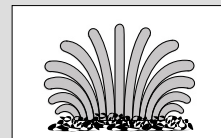

T.montana, T.magna
Tubifera ferruginosa
$R$. reticulata
Rigidotubula violacea,

Secondary

capillitium

1
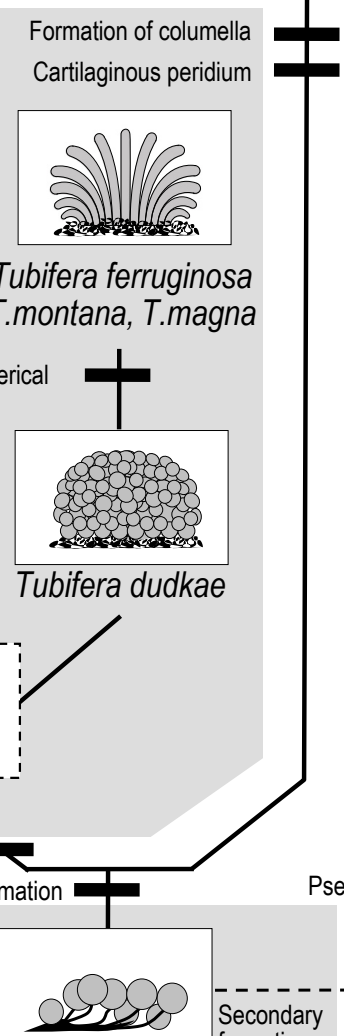

Alwisia repens of capilitium

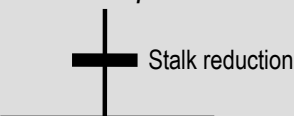

Alwisia morula

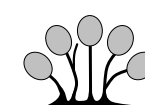

L

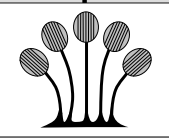

Alwisia lloydiae

\section{Reticularia lycoperdon}

Branched pseudocapilitium

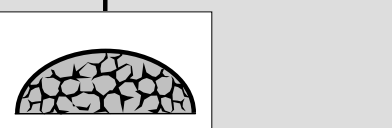

Reticularia

splendens,

$R$. jurana

Formation

of aethalium

of aethalium

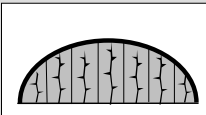

\section{Thecotubifera}

dictyoderma

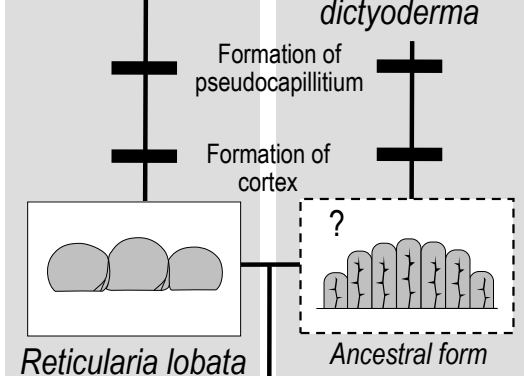

Reticularia lobata

Reduction of capillitium

Pseudoaethalium formation

Ancestral form

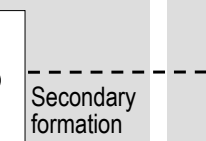

Lycogala epidendrum

Siphoptychium?
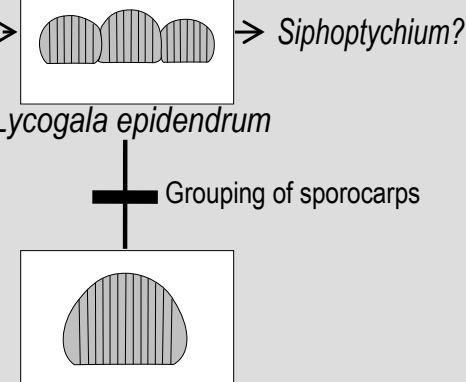

Lycogala conicum, L. exiguum
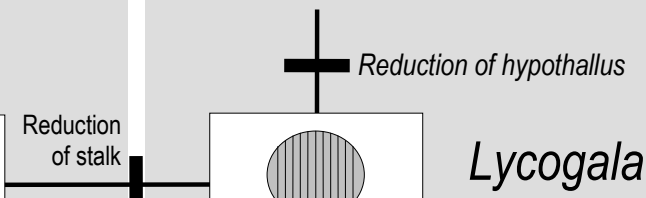

Last common ancestor

Fig. 2. Evolution of the sporophore in Reticulariaceae. The genealogy of taxa corresponds to the current understanding of the phylogeny of the group (see Fig. 1). Bars indicate the most important evolutionary changes. Dotted arrows show the alternative evolutionary scenarios. Gray filling unites the members of the same genus. 
(R. liceoides, R. olivacea, R. aurea, R. rubiginosa, $R$. simulans) on the basis of obtained data were excluded from the family Reticulariaceae. The first two species were removed to Cribrariaceae, with the simultaneous re-erection of the genus Licaethalium Rostaf. (Leontyev et al., 2015).

The current understanding of the phylogeny of Reticulariaceae, based on these data, is shown in Fig. 1.

The results obtained have allowed to look at the morphological diversity of Reticulariaceae from a new point. In contrast to the traditional understanding, the family appeared to include species with stalked and sessile sporocarps (Alwisia lloydiae, A. repens, A. morula), pseudoaethalia with the entire cortex (Thecotubifera dictyoderma) and pseudoaethalia, composed of spherical sporothecae (Tubifera dudkae). The true capillitium was found to be rather common structure within the family, being developed in Alwisia, Lycogala and Siphoptychium, while the threads, described in sporocarps of Tubifera (Nannenga-Bremekamp, 1991; Neubert et al., 1993), appeared to be fungal hyphae, feeding with the spores, but not a capillitium (Leontyev et al., 2015).

New knowledge about the phylogeny of the group, together with a deeper understanding of its morphological variability, gives us a chance to understand how the structure of these organisms was changed in the process of evolution. In a response to this possibility, we composed a concept which describes regularities of the evolutionary changes of the sporophore structure in Reticulariaceae (Fig. 2).

According to the 18S rDNA phylogeny (Fig. 1), the basis of the evolutionary tree of the Reticulariaceae is formed by the genus Alwisia. This correlates with its morphological features, among which the type of sporophore is of greatest importance. It is proven that the primary type of myxomycetes sporophore is the stalked sporocarp: such fructifications are typical for all sister groups of myxomycetes (Dictyodtelia, Ceratiomyxales, Protostelia s. 1.), and also for the Echinosteliales, the order which is believed to be closest to the last common ancestor of myxomycetes (FioreDonno et al., 2005; 2008; 2012). Within Lucisporidia (the bright-spored myxomycetes), the basal position is occupied by the Cribrariaceae, most of which also have stalked sporocarps. Finally, this is the only type of the fruiting body known in all the orders of Myxogastrea. Therefore, the presence of this structure makes Alwisia the best candidate for the role of the last common ancestor of Reticulariaceae.
The next plesiomorphic character of Alwisia is the presence of a well-developed capillitium, resembling that of another bright-spored myxomycetes, Dianemataceae and Trichiaeceae. This similarity supports a hypothesis that the presence of capillitium is the basal characteristic for the Reticularaceae and for the Lucisporodia in general.

Among species of Alwisia, two are characterized by well developed, free stalks, and another two (A. bombarda, A. lloydiae) - by the presence of capillitium (A. morula, A. lloydiae). There is only one known species, which unites both plesiomorphies lost by most of Reticulariaceae, the A. lloydiae, which we consider as the closest to the last common ancestor of the family. It is noteworthy that this species occurs in the Australian continent and in Tasmania, the well known refuges of a relict biota.

From the basal form, related with A. lloydiae, at least three evolutionary lineages have originated. First of them is represented by the vector $A$. lloydiae $\rightarrow$ $A$. morula $\rightarrow A$. repens, in which the sporothecae lose the capillitium (A. morula) and their stalks become procumbent (A. repens). We suppose that this lineage has continued in the genera Tubifera, Rigidotubula, and probably Siphoptychium. Simultaneously to the loss of capillitium and stalks, the spore dissemination type changed from the active way, with the help of capillitium, to the passive one, using rain drops and/or insects.

Another vector is formed by species which did not lose the capillitium but grouped their sporothecae in a common confluent stalk (A. bombarda). Sporothecae became thinner, as it happens in all Reticulariaceae with tightly grouped sporothecae (see below).

Finally, the third lineage joins Alwisia with the phylogenetic cluster, which unites Lycogala, Thecotubifera and Reticularia. The consequence of branching of this contemporary genera from Alwisia-like ancestor is not yet clear; however, taking into account the attribution of sporophores of Lycogala to the free sporocarps (Leontyev et al., 2014c), this genus appears to be the most «archaic» representative of the group. This is noteworthy that among Lycogala, Thecotubifera and Reticularia, the only first genus has the tubular capillitium, close in its morphology, ultrastructure and ontogenesis to that of Alwisia.

The lineage which binds $A$. lloydiae with the genus Tubifera, is divided to two subclades that we call «smallspored» and «large-spored» (Leontyev et al., 2015). First of them includes the species of Tubifera with the 
spores less than $6.5 \mu \mathrm{m}$ diam., mostly annulate and noniridescent peridium, flattened apices of sporothecae and a dull pigmentation of the young sporophores. Another subclade consists of the species with the spores larger than $6.5 \mu \mathrm{m}$, mostly iridescent peridium, covered with wavy folds, the convex apices of sporothecae and bright pigmentation of immature sporophores. These two subclades within Tubifera must have a common ancestor. It probably had spherical sporothecae, found in its evolutionary predecessor, A. repens. However, in contrast with the last one, common ancestor of Tubifera should have a spongy hypothallus, which is absent in all Alwisia, but well developed in both subclades of Tubifera . The structure, which meets these requirements, occurs in T. dudkae which belongs to the «large-spored» clade.

All other species of the «large-spored» clade (T. ferruginosa, T. magna, T. montana) have cylindrical sporothecae, the presence of which seems to be the usual result of the accretion of sporothecae in Reticulariaceae.

Independently, the transformation of spherical sporothecae to cylindrical ones took place in the «small-spored» clade. However, in this case we know contemporary species which retained both types of sporothecae: T. corymbosa, in which all cylindrical and spherical sporothecae are seated on spongy hypothallus, and $T$. dimorphotheca, in which spherical sporothecae are situated on the lateral surface of the hypothallic stalk, while cylindrical ones occupy its top. The reduction of spherical sporothecae in $T$. dimorphotheca could produce the forms similar to $T$. microsperma and T. pseudomicrosperma.

The formation of the hypothallic stalk, characteristic to $T$. dimorphotheca and T. microsperma, correlates with the decreasing of the size of pseudoaethalium. This suggests that the recovery of the stalks, completely lost in the previous stages of Tubifera evolution, was caused by the partial return to the strategy of the stalked sporocarp, because the distribution using the rain drops and insects is effective only in large fruiting bodies (Schnittler, 2002).

The point of divergence, which led to the formation of $T$. applanata within the «small-spored» clade, remains unclear. This species is the only member of the subcluster, which have large, sessile pseudoaethalia with closely accreted prismatic sporothecae. Its origin from an ancestor, common with $T$. corymbosa, looks the most «parsimonic» scenario: it needs only the loss of spherical sporothecae, while any other hypotheses claim for the reduction of hypothallic stalk. Molecular data support the origination of $T$. applanata and $T$. corymbosa from the common ancestor.
Sporophores of the genera Rigidotubula and Siphoptychium represent a further development of tubiferoid pseudoaethalia with prismatic sporothecae, which have got the cartilaginous peridium and columella. With the appearance of these structures, the Rigidotubula can be easily derived from $T$. applanata. However, the molecular data do not support this simple scenario and show that Rigidotubula has branched from the trunk of Tubifera even before the last one was subdivided on «small-» and «large-spored» clades, and therefore, before Tubifera formed pseudoaethalia with cylindrical sporothecae. It means that Rigidotubula should has gone all the way from the heap of spherical sporothecae to the pseudoaethalium, composed of prismatic ones, independently from Tubifera. This is a prominent example of parallel evolution.

The absence of molecular data about the phylogenetic relations of the genus Siphoptychium does not allow to determine its position in our evolutionary scheme. However, the complex of morphological features, like a prismatic sporothecae, cartilaginous peridium and well developed columella, puts this genus close to Rigidotubula. On the other hand, it should be noted that the most important feature of Siphoptychium is the branching of columella and the presence of the perforations at the places where columella merges the peridium. Both of these features bring Siphoptychium close to Alwisia (the last one does not have columella, but its capillitial threads have a similar structure and ornamentation with the branches of columella in Siphoptychium). Therefore, Siphoptychium may represent a separate lineage of pseudoaethaliate forms that comes directly from Alwisia-like ancestor.

The Lycogala inherited from Alwisia its tubular capillitium, but not the stalk. Its sessile sporocarps are the most probable predecessors of the aethalia known in Reticularia. The stage, intermediate between grouped sporocarps and aethalium, is known within this lineage only in Thecotubifera, where the fruiting body consists of prismatic sporothecae which form together an entire, indivisible cortex. This allows to imagine a simple evolutionary scenario, such as: Lycogala (sessile sporocarps) $\rightarrow$ Thecotubifera (pseudoaethalia) $\rightarrow$ Reticularia (aethalia). However, at least one reason does not allow to support this hypothesis. Peculiarities of the spores in Th. dictyoderma, such as very large meshes with high borders, separate this species from all another Reticulariaceae, while in Reticularia the spore ornamentation istypical for the family (small meshes with relatively low borders). It is unlikely that the ancestors of 
Reticularia once lost a typical ornamentation, and then developed it again. Moreover, the species of Reticularia with well-developed pseudocapillitium ( $R$. splendens, $R$. jurana) show the remnants of confluence of spherical, bag-shaped or vermicular sporothecae, but not straight and prismatic ones, like those in Thecotubifera. Thus, much preferable is the scenario of independent origin of Reticularia and Thecotubifera from a common ancestor, that had a rudimentary pseudoaethalia (such a form is yet unknown) or sporocarps (Lycogala). A link between Lycogala and Reticularia can represent $R$. lobata, since the latter, according to our assumption, has not aethalia, but spherical sporocarps, that form the primitive pseudoaethalia. This corresponds to the characters of pseudoaethaliate ancestor of aethaliate Reticularia, because, as noted above, it probably did not have cylindrical sporothecae. The structure of sporophores in $R$. lobata is very close to L. epidendrum and differs from the latter only by lack of tubular capillitium, the loss of which took place here independently from the vector Alwisia $\rightarrow$ Tubifera.

The abovementioned discussion allows to make several conclusions:

1. The general tendency of the morphological evolution in Reticulariaceae is the transformation of the stalked forms to the sessile ones, followed by the formation of pseudoaethalia and aethalia. Simultaneously, the spore dissemination type was changed from the active way with the help of capillitium to the passive one, through rain and insects.

2. The common ancestor of the family had stalked sporocarps with well-developed tubular capillitium and was similar in structure to Alwisia lloydiae. This ancestral form produced at least four evolutionary lineages: 1) Alwisia $\rightarrow$ Tubifera, 2) Alwisia $\rightarrow$ Rigidotubula (and Siphoptychium, if it does not form a separate branch), 3) Alwisia $\rightarrow($ Lycogala $) \rightarrow$ Thecotubifera, 4$)$ Alwisia $\rightarrow$ Lycogala $\rightarrow$ Reticularia lobata $\rightarrow$ aethalial species of Reticularia.

3. The evolution of the fruiting bodies in Reticulariaceae is characterized by the parallelism. Processes like a loss of stalks, transition from spherical to elongated sporothecae, transformation of sporocarps to pseudoaethalia and aethalia, loss of capillitium and formation of pseudocapillitium have occurred repeatedly. Therefore, the morphological similarity of the fruiting bodies does not necessarily indicate the affinity of species. A type of the fruiting body cannot be considered as a sufficient criterion for the separation of the genera in myxomycetes.

\section{REFERENCES}

Fiore-Donno A.M., Berney C., Pawlowski J., Baldauf S.L. Higher-order phylogeny of plasmodial slime molds (Myxogastria) based on Elongation Factor 1-A and Small Subunit rRNA gene sequences, J. Eukaryot. Microbiol., 2005, 52: 1-10.

Fiore-Donno A.M., Meyer M., Baldauf S.L., Pawlowski J. Evolution of dark-spored Myxomycetes (slime-molds): molecules versus morphology, Mol. Phylogenet. Evol., 2008, 46: 878-889.

Fiore-Donno A.M., Kamono A., Meyer M., Schnittler M., Fukui M., Cavalier-Smith T. 18S rDNA phylogeny of Lamproderma and allied genera (Stemonitales, Myxomycetes, Amoebozoa), PLoS One, 2012, 7(4): e35359.

Ing B. The Myxomycetes of Britain and Ireland. An identification Handbook, Slough: The Richmond Publishing Co. Ltd., 1999, 374 pp.

Lado C., Pando F. Myxomycetes. In: Flora Mycologica Iberica, Madrid: Real Jardín Botánico, J. Cramer, 1997, vol. 1, 324 pp.

Leontyev D., Schnittler M., Moreno Horcajada G., Stephenson S., Mitchell D.W., Rojas C. The genus Alwisia (Myxomycetes) revalidated, with two species new to science, Mycologia, 2014a, 106(5): 936-948.

Leontyev D.V., Schnittler M., Stephenson S.L. A new species of Alwisia (Myxomycetes) from new South Wales and Tasmania, Mycologia, 2014b, 106(6): 1212-1219.

Leontyev D.V., Schnittler M., Stephenson S.L. Pseudocapillitium or true capillitium? A study of capillitial structures in Alwisia bombarda (Myxomycetes), Nova Hegwigia, 2014c, 99(3-4): 441-451.

Leontyev D., Schnittler M., Stephenson S.L. A critical revision of the Tubifera ferruginosa complex, Mycologia, 2015, 107(5): 959-985.

Leontyev D.V. Ukr. Bot. J., 2015, 72(2): 147-155. doi. org/10.15407/ukrbotj72.02.147 [Леонтьєв Д.В. Перспективи створення філогенетичної системи міксоміцетів (Mухоgastrea) // Укр. ботан. журн. - 2015. - 72(2). - C.147-155].

Nannenga-Bremekamp N.E. A Guide to Temperate Myxomycota, Bristol: Biopress Ltd., 1991, 410 pp.

Neubert H., Nowotny W., Baumann K. Die Myxomyceten Deutschlands und des angrenzenden Alpenraumes unter besonderer Berücksichtigung Österreichs, Gomaringen: Karlheinz Baumann Verlag., 1993, vol. 1, 340 S.

Poulain M., Meyer M., Bozonnet J. Les Myxomycètes, Dauphiné-Savoie: Fédération mycologique et botanique, 2011, vol. 1, 568 pp.

Schnittler M. The evolution of the myxomycete fructification - an independent approach of life to achieve macroscopic organisms? In: Abstracts of the Fourth International Congress of the Systematics and Ecology of Myxomycetes, Brusseles: Universa, 2002, p. 82.

Recommended by

V.P. Hayova
Submitted 05.10.2015 
Леонтьєв Д.В. Еволюція спорофора у Reticulariaceae (Myxomycetes). - Укр. ботан. журн. - 2016. -73(2): 178-184.

Харківська державна зооветеринарна академія, кафедра біотехнології

вул. Академічна, 1, Мала Данилівка, Харків, 62341, Україна

Молекулярно-генетичні дослідження прояснили філогенетичні відносини між таксонами родини Reticulariaceae (Myxomycetes, Myxogastrea), надали змогу реконструювати шляхи морфологічної еволюції цього таксона. Згідно 3 одержаними даними загальною тенденцією еволюції спорофорів у Reticulariaceae є трансформація стебельчастих форм у сидячі, яка супроводжувалася формуванням 3 вільних спорокарпів метамерних плодових тіл - псевдоеталіїв та еталіїв. Спільний предок родини був подібний до сучасної Alwisia lloydiae і мав стебельчасті спорокарпи та трубчастий капіліцій. Від цього предка започатковані принаймні чотири філогенетичні лінії: Alwisia $\rightarrow$ Tubifera; Alwisia $\rightarrow$ Rigidotubula (та, ймовірно, Siphoptychium); Alwisia $\rightarrow($ Lycogala $) \rightarrow$ Thecotubifera; Alwisia $\rightarrow$ Lycogala $\rightarrow$ Reticularia. У кожній із цих ліній незалежно відбувалися такі еволюційні процеси, як втрата ніжок, перехід від сферичних до циліндричних споротек і від одиночних до згрупованих спорокарпів, втрата капіліцію та формування псевдокапіліцію. Зважаючи на це, тип плодового тіла та наявність капіліцію або псевдокапіліцію не можуть розглядатися як вирішальні критерії для розмежування родів міксоміцетів.

Ключові слова: $18 \mathrm{~S}$ рДНК, еталій, капіліцій, паралелізм, філогенія, псевдоеталій, псевдокапіліцій, орнаментація спор, спорокарп, споротека.
Леонтьев Д.В. Эволюция спорофора у Reticulariaceae (Myxomycetes). - Укр. ботан. журн. - 2016. -73(2): 178-184.

Харьковская государственная зооветеринарная академия, кафедра биотехнологии ул. Академическая, 1, Малая Даниловка, Харьков, 62341, Украина

Молекулярно-генетические исследования прояснили филогенетические взаимоотношения между таксонами семейства Reticulariaceae (Myxomycetes, Myxogastrea), дав возможность реконструировать пути морфологической эволюции этого таксона. Согласно полученным данным, общей тенденцией в эволюции спорофора Reticulariaceae является трансформация стебельчатых форм в сидячие, сопровождавшаяся формированием из свободных спорокарпов метамерных плодовых тел - псевдоэталиев и эталиев. Общий предок семейства был близок к современной Alwisia lloydiae; он имел стебельчатые спорокарпы и трубчатый капиллиций. От этого предка берут начало, по крайней мере, четыре филогенетические линии: Alwisia $\rightarrow$ Tubifera; Alwisia $\longrightarrow$ Rigidotubula (и, вероятно, Siphoptychium); Alwisia $\rightarrow($ Lycogala $) \rightarrow$ Thecotubifera; Alwisia $\rightarrow$ Lycogala $\rightarrow$ Reticularia. В каждой из этих линий независимо происходили такие эволюционные процессы, как потеря ножек, переход от сферических споротек к цилиндрическим и от одиночных спорокарпов к сгруппированным, потеря капиллиция и формирование псевдокапиллиция. В связи с этим тип плодового тела, а также наличие капиллиция и псевдокапиллиция не могут рассматриваться в качестве решающих критериев для разграничения родов миксомицетов.

Ключевые слова: $18 \mathrm{~S}$ рДНК, эталий, капиллиций, параллелизм, филогения, псевдоэталий, псевдокапиллиций, орнаментация спор, спорокарп, споротека.

\section{НОВІ ВИДАННЯ}

Savchenko K.G., Wasser S.P., Heluta V.P., Nevo E. Smut fungi of Israel (Biodiversity of Cyanoprocaryotes, Algae and Fungi of Israel) / Institute of Evolution and Faculty of Natural Sciences, University of Haifa, Israel. - Koeltz Scientific Books, 2015. - $160 \mathrm{p}$.

The book covers smut fungi (Ustilaginomycetes p.p., Exobasidiomycetes p.p., and Microbotryales) of Israel. A total of 73 species in 15 genera are described. Three genera (Macalpinomyces, Melanustilospora and Schizonella) are new records for Israel. The book is divided into two main parts: General Part providing data regarding environmental conditions of Israel, morphology of smut fungi, materials and methods, historical studies, as well as the analysis of species composition of smut fungi in Israel; Special Part (taxonomic part) providing information regarding detailed macro- and micromorphological descriptions, distribution in Israel, general distribution, and notes.

Видання охоплює сажкові гриби (Ustilaginomycetes p.p., Exobasidiomycetes p.p. і Microbotryales) Ізраїлю. Описано 73 види з 15 родів, три роди (Macalpinomyces, Melanustilospora i Schizonella) є новими для Ізраїлю. Книга складається з двох основних частин. Загальна містить відомості про стан навколишнього середовища країни, морфологію сажкових грибів, аналіз їх видового складу в Ізраїлі, матеріали та методи, історію досліджень цих грибів. У спеціальній (таксономічній) частині монографії наводиться детальна інформація про макро- та мікроморфологію видів сажкових грибів, їхнє поширення в Ізраїлі та світі, подано також примітки. 